\title{
Saponin-based Mycoplasma bovis vaccine containing lysozyme dimer adjuvant stimulates acute phase response in calves
}

\author{
Katarzyna Dudek, Dariusz Bednarek \\ Department of Cattle and Sheep Diseases, \\ National Veterinary Research Institute, 24-100 Pulawy, Poland \\ katarzyna.dudek@piwet.pulawy.pl
}

Received: May 29, 2018

Accepted: September 20, 2018

\begin{abstract}
Introduction: Mycoplasma bovis is known as a causative agent of many disorders in cattle. In Europe, there is still a lack of commercial vaccines against $M$. bovis infection. Acute phase response (APR) is a non-specific host reaction to infection, most seen in changes in production of acute phase proteins. The aim of this study was to analyse APR in calves administered with an experimental M. bovis vaccine. Material and Methods: Twelve healthy female calves were divided into two equal groups: experimental and control. The experimental vaccine containing the field M. bovis strain and two adjuvants such as saponin and lysozyme dimer was subcutaneously administered to the experimental group. Phosphate buffered saline was taken as the placebo and given to the control group by the same route as the vaccine. Blood samples were collected prior to the study (day 0 ), then daily up to day 7 , and then each seven days until day 84 post vaccination. The concentrations of serum amyloid A (SAA), haptoglobin (Hp), interferon- $\gamma$ (IFN- $\gamma$ ), and inteleukin-4 (IL-4) were determined using commercial ELISA kits. Results: Following the vaccination, a significant increase in SAA, Hp, and IFN- $\gamma$ concentrations was observed when compared to the unvaccinated calves, whereas the IL-4 concentration was not detectable. Conclusion: The experimental saponin-based M. bovis vaccine containing lysozyme dimer adjuvant visibly stimulated the APR in the calves, and some specific cytokines (Th1-dependent) directly involved in this response.
\end{abstract}

Keywords: calves, Mycoplasma bovis, vaccine, saponin, lysozyme, acute phase proteins, cytokines.

\section{Introduction}

Acute phase response (APR) is known as a nonspecific host reaction following infection, inflammation, or injury, and the reaction includes immunological, metabolic, and other changes which lead to the restoration of homeostasis. One of the most spectacular disorders during APR are changes in production of acute phase proteins (APPs) in the liver as well as in extrahepatic tissues, which are mediated by cytokines (2). The most indicatory APPs in cattle are serum amyloid A (SAA) and haptoglobin (Hp), both known as positive APPs, of which production increases during APR. It was previously shown that SAA acts as a fast-responding APP, whereas Hp concentration rises more slowly following inflammation (24). SAA and $\mathrm{Hp}$ were previously recognised as biomarkers of many diseases in cattle such as mastitis, metritis, and other reproductive disorders like retained placenta $(3,19,21)$. Their diagnostic significance has recently also increased in bovine non-infectious diseases such as ketosis, ruminal acidosis, or displaced abomasum $(4,13,27)$.

Mycoplasma bovis causes many disorders in cattle, including pneumonia, arthritis, and mastitis. As was demonstrated in our previous studies, M. bovis is able to stimulate APR $(7,10)$. However, little is known about APP and cytokine response following vaccination against this pathogen. This study used a saponin-based experimental $M$. bovis vaccine containing lysozyme dimer as adjuvant. Saponin-based vaccines given alone or combined with Emulsigen adjuvant were previously used successfully in experimental studies $(6,20)$. Lysozyme dimer has numerous applications including immunostimulation, prophylaxis, and treatment of many diseases in cattle such as mastitis, metritis, cystic ovary disease, gastroenteritis, or bronchopneumonia $(5,14,15,16,17)$. 
However, until now it had not found any application in studies on vaccines.

The aim of the study was to analyse the APR in the calves administered with the experimental saponinbased $M$. bovis vaccine containing lysozyme dimer as adjuvant.

\section{Material and Methods}

Animals. Twelve 5-week-old clinically healthy female calves of Holstein-Friesian breed were tended through a two-week adaptation and then divided into two equal groups: an experimental group administered the vaccine with saponin and lysozyme $(\mathrm{S}+\mathrm{L})$ and a control (C). Animals from each group were housed separately, fed milk replacer twice a day and hay, and given water ad libitum.

Vaccine preparation and calf immunisation. The vaccine containing the field $M$. bovis strain (BankIt 1801634 MBovis KP795974) and the two adjuvants saponin (Sigma-Aldrich, Germany) and lysozyme dimer (Lydium-KLPTM, Nika Health Products, Poland) was prepared according to the method described previously by Dudek et al. (12) and administered subcutaneously to the $\mathrm{S}+\mathrm{L}$ group in total volume of $8 \mathrm{~mL}$ and a final concentration of $6.25 \times 10^{7} \mathrm{CFU} / \mathrm{mL}$. Phosphate buffered saline (PBS) was taken as the placebo and given to the controls by the same route as vaccine.

Samples. Blood samples were collected from each calf prior to the study (day 0 ), then daily up to day 7 , and then every seven day until day 84 post vaccination. After collection, the blood samples were centrifuged at $1,500 \mathrm{~g}$ for $10 \mathrm{~min}$ to obtain sera. Before analyses, the sera were stored at $-20^{\circ} \mathrm{C}$.

Methods. The concentrations of SAA and $\mathrm{Hp}$ were determined using two separate commercial ELISA kits (Tridelta Development Ltd., Ireland), and other commercial ELISAs were used for assaying the content of cytokines IFN- $\gamma$ (ID.vet Innovative Diagnostics, France) and IL-4 (Uscn Life Science Inc.,
China). All tests were performed according to the manufacturer's instructions. The optical densities were read using an ELx800 automated microplate reader (BioTek Instruments, USA) according to the KC Junior programme (BioTek Instruments).

Statistical analysis. The results are presented as arithmetic means \pm standard deviation. Student's $t$ test was used to analyse the differences between the mean values recorded in the $\mathrm{S}+\mathrm{L}$ and control groups at the same time point with a statistically significant level of $\mathrm{P}<0.05$.

\section{Results}

No adverse reactions such as fever, oedema at injection sites, etc. were observed following calf vaccination. The $M$. bovis-specific antibodies, bovine total $\operatorname{Ig}$ and $\operatorname{IgG}$, $\operatorname{IgA}$, and $\operatorname{IgM}$ classes as well as peripheral blood lymphocyte immunophenotyping were determined in the vaccinated calves, and the results were shown in our previous studies $(11,12)$.

The SAA concentration was nearly seven times higher on day 1 post vaccination when compared to the control, whereas on day two it was 12 times higher in the experimental calves than in the control. A visibly elevated SAA concentration was observed in the $\mathrm{S}+\mathrm{L}$ group up to day 6 post vaccination and again on days 49, 56, 77, and 84 (Fig. 1). Starting from day 1 post vaccination, the $\mathrm{Hp}$ concentration was visibly higher than the control and continued to be on day 2. On the remaining days post injection, this concentration was not detectable (Fig. 2). During the first two days post vaccination, IFN- $\gamma$ was visibly more concentrated when compared to the control. On the remaining days of the study this cytokine was comparably or slightly less concentrated in the experimental calves than in the controls, whereas on day 84 IFN- $\gamma$ had again become more concentrated in the $\mathrm{S}+\mathrm{L}$ group (Fig. 3). The IL-4 concentration was not detectable in the two groups throughout the study.

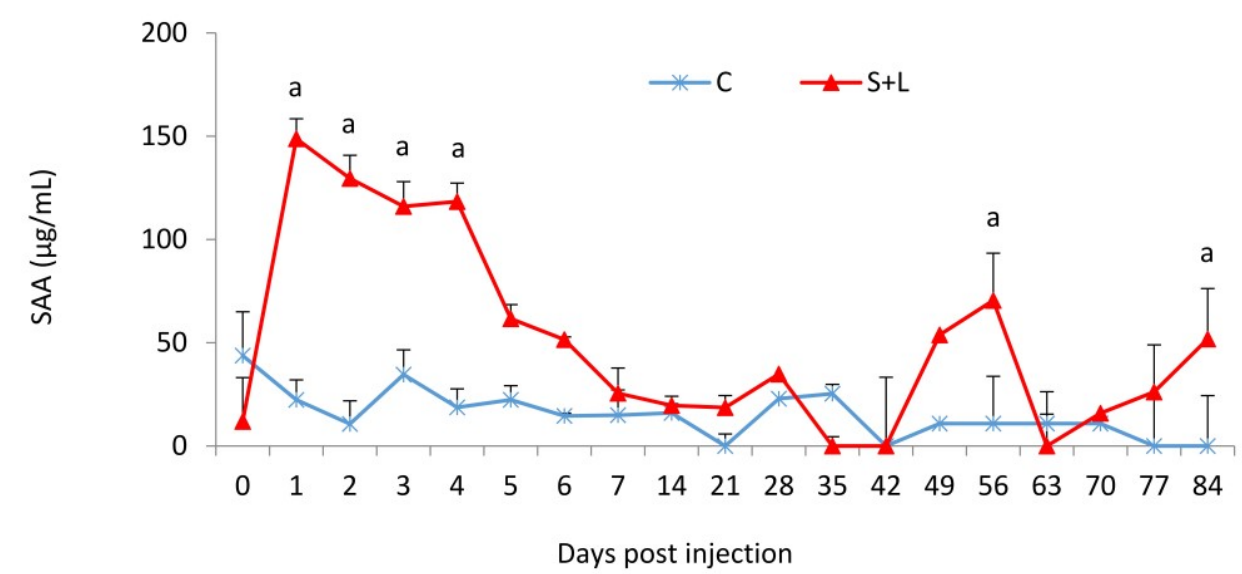

Fig. 1. Serum SAA concentration in the vaccinated $(S+L)$ and control calves $(C)$. The letter a denotes $\mathrm{P}<0.05$ between groups $\mathrm{S}+\mathrm{L}$ and $\mathrm{C}$ 


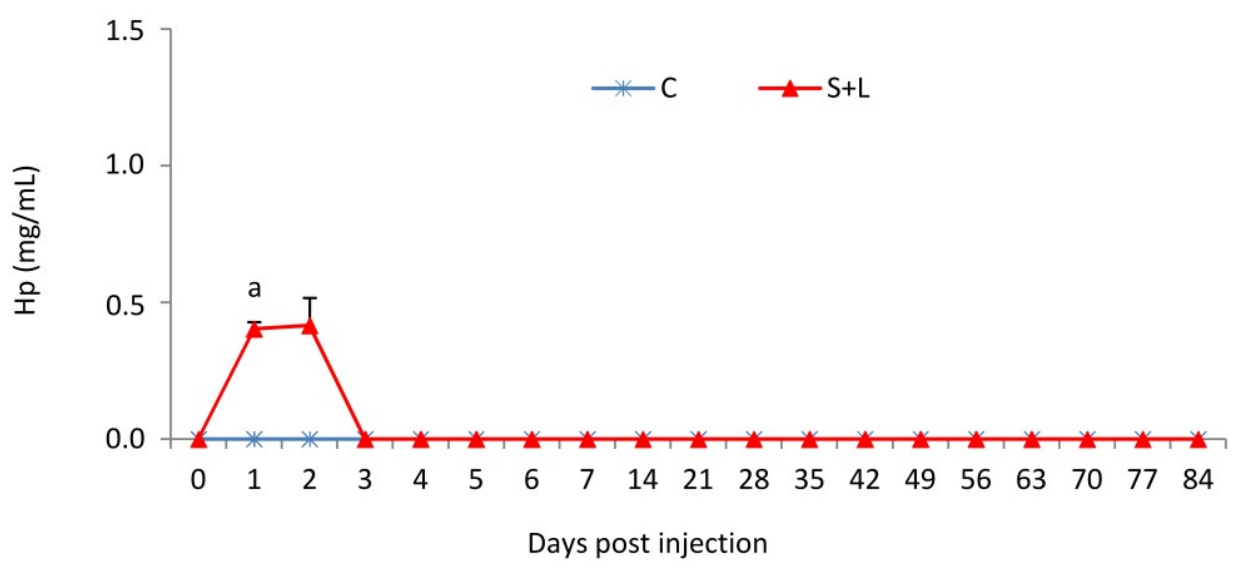

Fig. 2. Serum Hp concentration in the vaccinated $(\mathrm{S}+\mathrm{L})$ and control calves $(\mathrm{C})$. The letter a denotes $\mathrm{P}<0.05$ between groups $\mathrm{S}+\mathrm{L}$ and $\mathrm{C}$

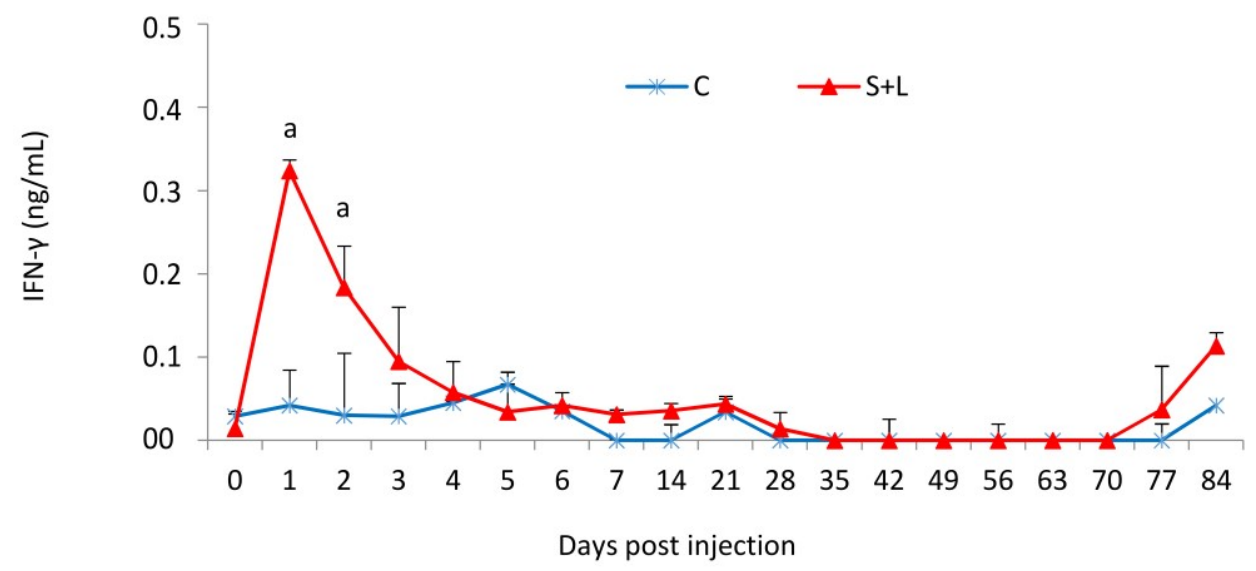

Fig. 3. Serum IFN $-\gamma$ concentration in the vaccinated $(\mathrm{S}+\mathrm{L})$ and control calves $(\mathrm{C})$. The letter a denotes $\mathrm{P}<0.05$ between groups $\mathrm{S}+\mathrm{L}$ and $\mathrm{C}$

\section{Discussion}

It was previously demonstrated that our experimental M. bovis vaccine containing saponin and lysozyme dimer as adjuvants visibly stimulated cellmediated immunity in the calves. It was expressed by enhanced T- and B-cell response (12). Moreover, humoral immune response was also activated following the vaccination, most evidently seen in considerably increased specific antibodies to $M$. bovis and bovine IgG concentration (11).

Our previous study showed that intratracheal inoculation with a field $M$. bovis strain caused a significant increase in the SAA and $\mathrm{Hp}$ concentrations in the affected calves (10). This observation was in agreement with our other results in which three $M$. bovis isolates of different origins were used in a calf challenge (7). Similar findings were also made in field conditions where visible stimulation of SAA and $\mathrm{Hp}$ production was observed in cattle seropositive for M. bovis (9). The biological functions of SAA are wide in range, but one of the well- recognised phenomena is opsonisation which in cattle affects both $\mathrm{Gram}^{+}$and $\mathrm{Gram}^{-}$bacteria (18). Another beneficial function of SAA, but one not fully proven in cattle, is its chemotactic activity towards some white blood cells $(2,25)$. Thus, visible SAA stimulation during the first days post vaccination seems to show an enhancement of antimicrobial defence mechanisms in the vaccinated calves. The other positive APP, Hp with its slower response, also increased in amount during the first two days post vaccination; but this response was less pronounced than that of SAA. General stimulation of both SAA and Hp production was also observed following calf administration with the saponin-based $M$. bovis vaccine given alone, in combination with Emulsigen, or with both Emulsigen and $\alpha$-tocopherol acetate as adjuvants (8). The main functions of $\mathrm{Hp}$, weakly recognised in cattle, however, are its antioxidant and anti-inflammatory activities. It was previously demonstrated that Hp modulates immune response also via suppression of production of some Th2-skewed cytokines in vitro (1). In a recent study, no response by way of expression of IL-4, a cytokine 
derived from Th2 lymphocytes, was observed following vaccination. In contrast, the production of IFN- $\gamma$, known to be a Th1-skewed cytokine, was markedly stimulated in the vaccinated calves. Accordant results were found in our previous study when the stimulation of IFN- $\gamma$ production was observed in calves administered with the saponin-based M. bovis vaccines regardless of adjuvant used (8). In contrast to the observation in the recent study, the distinct but short IL-4 response was discernible in the calves administered with the vaccines containing Emulsigen ${ }^{\circledR}$ or both Emulsigen ${ }^{\circledR}$ and $\alpha$-tocopherol acetate adjuvants (8). Soehnlen et al. (23) reported no significant changes in IFN- $\gamma$ or IL- 4 concentrations in the calves treated with two different $M$. bovis bacterin vaccines. It was previously shown that immune response to $M$. bovis infection is regulated by IL- 4 rather than IFN- $\gamma$, and it is Th2-dependent (26). Thus, the distinct stimulation of IFN- $\gamma$ production in the vaccinated calves could result from the adjuvant effect rather than the bacteria, especially since it was previously shown that lysozyme dimer is able to stimulate some cytokine production in pigs, including IFN- $\gamma(22)$.

The experimental saponin-based $M$. bovis vaccine containing lysozyme dimer adjuvant visibly stimulated the APR in the calves and some specific cytokines (Th1-dependent) directly involved in this response.

Conflict of Interests Statement: The authors declare that there is no conflict of interests regarding the publication of this article.

Financial Disclosure Statement: This study was financed by statutory research funds from the Polish Ministry of Science and Higher Education assigned to the Department of Cattle and Sheep Diseases, National Veterinary Research Institute.

Animal Rights Statement: The authors declare that the experiments on animals were conducted in accordance with laws and regulations of the $2^{\text {nd }}$ local Ethical Committee for Animal Experiments in Lublin as regards care and use of laboratory animals.

\section{References}

1. Arredouani M.S., Kasran A., Vanoirbeek J.A., Berger F.G., Baumann H., Ceuppens J.L.: Haptoglobin dampens endotoxininduced inflammatory effects both in vitro and in vivo. Immunology 2005, 114, 263-271.

2. Ceciliani F., Ceron J.J., Eckersall P.D., Sauerwein H.: Acute phase proteins in ruminants. J Proteomics 2012, 75, 4207-4231.

3. Chan J.P., Chang C.C., Hsu W.L., Liu W.B., Chen T.H.: Association of increased serum acute-phase protein concentrations with reproductive performance in dairy cows with postpartum metritis. Vet Clin Pathol 2010, 39, 72-78.

4. Danscher A., Thoefner M., Heegaard P., Ekstrom C., Jacobsen S.: Acute phase protein response during acute ruminal acidosis in cattle. Livest Sci 2011, 135, 62-69.

5. Dembiński Z., Malinowski E., Kiczka W., Bronicki M., Kuźma R.: Application of Lydium-KLP (dimer of lysozyme) in treatment of inflammation of endometrium in cows. Proc. XVII Buiatrics Congress, Bologna, 1994, pp. 321-324.

6. Dudek K., Bednarek D., Ayling R.D., Kycko A., Szacawa E., Karpińska T.A.: An experimental vaccine composed of two adjuvants gives protection against Mycoplasma bovis in calves. Vaccine 2016, 34, 3051-3058.

7. Dudek K., Bednarek D., Ayling R.D., Szacawa E.: Immunomodulatory effect of Mycoplasma bovis in experimentally infected calves. Bull Vet Inst Pulawy 2013, 57, 499-506.

8. Dudek K., Bednarek D., Ayling R.D., Szczotka M., Iwan E., Kocki J.: Analysis of the immune response of calves to various saponin-based adjuvants for an experimental Mycoplasma bovis vaccine. Acta Vet Hung 2018, 66, 226-240.

9. Dudek K., Bednarek D., Szacawa E.: Evaluation of immune response in seropositive cattle for Mycoplasma bovis. Bull Vet Inst Pulawy 2011, 55, 631-634.

10. Dudek K., Bednarek D., Szymańska-Czerwińska M.: Acute phase response in calves as a result of experimental challenge with Mycoplasma bovis. Bull Vet Inst Pulawy 2010, 54, 517-520.

11. Dudek K., Bednarek D.: Humoral immunity in the calves experimentally vaccinated against Mycoplasma bovis infections. Med Weter 2017, 73, 425-428.

12. Dudek K., Bednarek D.: T- and B-cell response analysis following calf immunisation with experimental Mycoplasma bovis vaccine containing saponin and lysozyme dimer. J Vet Res 2017, 61, 433-437.

13. Huzzey J.M., Nydam D.V., Grant R.J., Overton T.R.: Associations of prepartum plasma cortisol, haptoglobin, fecal cortisol metabolites, and nonesterified fatty acids with postpartum health status in Holstein dairy cows. J Dairy Sci 2011, 94, 5878-5889.

14. Malinowski E., Kiczka W., Kondracki M., Pilaszek J., Nadolny M., Branicki T., Kuźma R.: Przydatność Lydium-KLP w leczeniu odoskrzelowego zapalenia płuc cieląt. (Effectiveness of Lydium-KLP in the treatment of calf bronchopneumonia) Życie Wet 1994, 69, 175-178.

15. Malinowski E., Kiczka W., Truszczyński M., Ziętara J., Nadolny M.: Przydatność Lydium-KLP w terapii gastroenteritis cieląt. (Effectiveness of Lydium-KLP in the treatment of calf gastroenteritis) Życie Wet 1994, 69, 172-175.

16. Malinowski E., Kłossowska A., Szalbierz M., Sobolewski J., Sobolewska S.: Przebieg ustępowania mastitis subclinica po iniekcji Lydium-KLP. (Disease course in subclinical mastitis following Lydium-KLP injection) Życie Wet 1996, 71, 304-306.

17. Malinowski E., Sobolewski J., Markiewicz H., Kiczka W., Klein P.,: A New method treatment of cystic ovary disease with Lydium-KLP. $13^{\text {th }}$ International Congress on animal Reproduction, Sydney, 1996, pp. 13-20.

18. Molenaar A.J., Harris D.P., Rajan G.H., Pearson M.L., Callaghan M.R., Sommer L., Farr V.C., Oden K.E., Miles M.C., Petrova R.S., Good L.L., Singh K., McLaren R.D., Prosser C.G., Kim K.S., Wieliczko R.J., Dines M.H., Johannessen K.M., Grigor M.R., Davis S.R., Stelwagen K.: The acute-phase protein serum amyloid A3 is expressed in the bovine mammary gland and plays a role in host defence. Biomarkers 2009, 14, 26-37.

19. Mordak R.: Postpartum serum concentration of haptoglobin in cows with fetal membranes retention. Cattle Pract 2009, 17, 100-102.

20. Nicholas R.A., Ayling R.D., Stipkovits L.P.: An experimental vaccine for calf pneumonia caused by Mycoplasma bovis: clinical, cultural, serological and pathological findings. Vaccine 2002, 20, 3569-3575.

21. Sadek K., Saleh E., Ayoub M.: Selective, reliable blood and milk bio-markers for diagnosing clinical and subclinical bovine mastitis. Trop Anim Health Prod 2017, 49, 431-437.

22. Siwicki A.K., Pejsak Z., Studnicka M., Klein P., Mokrzycka A., Rymuszka A., Bownik A.: Badania porównawcze nad wpływem dimeru lizozymu (KLP-602, Lydium-KLP) na komórkowe $\mathrm{i}$ humoralne mechanizmy obronne oraz poziom cytokin u prosiąt. 
(A comparative study on the effect of lysozyme dimer (KLP602, Lydium-KLP) on cellular and humoral defence mechanisms and cytokine levels in piglets). Materiały II Krajowego Sympozjum Immunologów Wet. (Proceedings of the II National Symposium on Veterinary Immunology), Świnoujście, 1997, p. 175 .

23. Soehnlen M.K., Aydin A., Lengerich E.J., Houser B.A., Fenton G.D., Lysczek H.R., Burns C.M., Byler L.I., Hattel A.L., Wolfgang D.R., Jayarao B.M.: Blinded, controlled field trial of two commercially available Mycoplasma bovis bacterin vaccines in veal calves. Vaccine 2011, 29, 5347-5354.

24. Stefaniak T.: Białka ostrej fazy u bydła (Acute phase proteins in cattle). In: Bialka ostrej fazy u zwierzat (Acute phase proteins in animals), edited by Kostro K., Gliński Z., Publisher Akademia Rolnicza in Lublin, Lublin, 2003, pp. 174-176.

25. Targowski S.P., Niemialtowski M.: Appearance of Fc receptors on polymorphonuclear leukocytes after migration and their role in phagocytosis. Infect Immun 1986, 52, 798-802.

26. Vanden Bush T.J., Rosenbusch R.F.: Characterization of the immune response to Mycoplasma bovis lung infection. Vet Immunol Immunopathol 2003, 94, 23-33.

27. Zarrin M., Wellnitz O., van Dorland H.A., Bruckmaier R.M.: Induced hyperketonemia affects the mammary immune response during lipopolysaccharide challenge in dairy cows. J Dairy Sci 2014, 97, 330-339. 